\title{
STUDIES OF THE METABOLISM OF HUMAN SPERMATOZOA
}

\author{
R. N. MURDOCH AND I. G. WHITE \\ Department of Veterinary Physiology, University of Sydney, \\ Sydney, N.S.W., Australia \\ (Received 17th fuly 1967, accepted 28th September 1967)
}

Summary. The metabolism of human spermatozoa has been studied
using concentrated suspensions of washed cells incubated with radio-
active substrates in small Warburg flasks, enabling the oxygen uptake
to be measured accurately.
Oxidative metabolism was greater at $\mathrm{pH} 7 \cdot 0$ than at $\mathrm{pH} 8 \cdot 5$. Phosphate
ions $(20 \mathrm{~mm})$ depressed oxidative metabolism at $\mathrm{pH} 7 \cdot 0$ but increased
it at $\mathrm{pH} 8 \cdot 5$. Fructolysis was stimulated by phosphate ions irrespective
of the $\mathrm{pH}$. Phosphate ions decreased the oxidation of lactate and
acetate by about the same absolute amount which suggests that it may
restrict the entry of acetyl CoA into the Krebs cycle.
Potassium ions (15 mm) increased both fructolysis and oxidative
metabolism, and bicarbonate increased the oxygen uptake.
Glucose and fructose were oxidized more readily than acetate, glycerol
or sorbitol, but only the polyols significantly increased the oxygen uptake.

\section{INTRODUGTION}

While there is abundant literature on the metabolic behaviour of the spermatozoa of several mammalian species, work on human spermatozoa is rather sparse. This has been mainly due to the low density of spermatozoa in the human ejaculate which makes it difficult to make an accurate estimate of metabolic activity.

Ross, Miller \& Kurzrok (1941) and MacLeod (1941) have shown that the oxygen consumption of human semen is predominantly associated with the seminal plasma and some workers have doubted the existence of true respiratory activity in human spermatozoa (MacLeod, 1943, 1956; MacLeod \& Freund, 1958). On the other hand, MacLeod (1943) and Mann (1951) have shown that human spermatozoa possess components of the cytochrome oxidase system and the latter author suggests that their metabolic pattern is essentially similar to that of other mammalian spermatozoa. The work of Terner (1960) and Nevo (1966) indicates the existence of an actively functioning oxidative system in human spermatozoa and Rothschild (1960) suggests that the use of phosphate buffer in manometric experiments has contributed to the belief that human spermatozoa do not respire. 
We have recently been able to obtain large volumes of freshly ejaculated human semen and by concentrating the spermatozoa and using ${ }^{14} \mathrm{C}$ labelled substrates in small manometer flasks, we have been able to measure their oxygen uptake with confidence and to extend knowledge of the metabolic behaviour of the human sperm cell.

Semen

\section{MATERIALS AND METHODS}

Semen was supplied by fourteen normal students and the time from collection to the start of the experiments was always less than $2 \mathrm{hr}$. Bull semen was collected with an artificial vagina.

\section{Diluents}

Experiment 2. (1) $\mathrm{pH} 7 \cdot 0$; no phosphate: $0.123 \mathrm{M}-\mathrm{NaCl}, 0.005 \mathrm{~m}-\mathrm{KCl}, 0.001$ $\mathrm{M}^{-\mathrm{MgSO}_{4}} \cdot 7 \mathrm{H}_{2} \mathrm{O}, 0.205 \mathrm{M}$-tris [tris-(hydroxymethyl)-amino-methane], 0.023 M-HCl.

(2) $\mathrm{pH} 7.0$; phosphate: $0.092 \mathrm{~m}-\mathrm{NaCl}, 0.005 \mathrm{~m}-\mathrm{KCl}, 0.001 \mathrm{~m}-\mathrm{MgSO}_{4} \cdot 7 \mathrm{H}_{2} \mathrm{O}$, 0.025 м-tris, $0.023 \mathrm{M}$-HCl, $0.012 \mathrm{~m}-\mathrm{Na}_{2} \mathrm{HPO}_{4} .12 \mathrm{H}_{2} \mathrm{O}, 0.008 \mathrm{~m}-\mathrm{NaH}_{2} \mathrm{PO}_{4}$. $2 \mathrm{H}_{2} \mathrm{O}$.

(3) $\mathrm{pH} 8.5$; no phosphate: $0 \cdot 123 \mathrm{M}-\mathrm{NaCl}, 0.005 \mathrm{M}-\mathrm{KCl}, 0.001 \mathrm{M}-\mathrm{MgSO}_{4}$. $7 \mathrm{H}_{2} \mathrm{O}, 0.037 \mathrm{~m}$-tris, $0.011 \mathrm{~m}-\mathrm{KCl}$.

(4) $\mathrm{pH} 8.5$; phosphate: $0.092 \mathrm{~m}-\mathrm{NaCl}, 0.005 \mathrm{~m}-\mathrm{KCl}, 0.001 \mathrm{м}-\mathrm{MgSO}_{4}$. $7 \mathrm{H}_{2} \mathrm{O}, 0.037 \mathrm{~m}$-tris, $0.011 \mathrm{~m}-\mathrm{HCl}, 0.020 \mathrm{M}-\mathrm{NaH}_{2} \mathrm{PO}_{4}$.

Where necessary, the buffers were adjusted to the respective $\mathrm{pH}$ with $\mathrm{NaOH}$. Experiment 3. Diluents (1) and (2) as above.

Experiment 4. 0.124 $\mathrm{M}-\mathrm{NaCl}$ and $0.016 \mathrm{M}$-sodium phosphate (Umbreit, Burris \& Stauffer, 1959) to which $0.015 \mathrm{M}-\mathrm{KCl}$ was added in place of the equivalent amount of $\mathrm{NaCl}$.

Experiments 5 and 6. Ca-free Krebs-Ringer phosphate buffer (Umbreit, Burris \& Stauffer, 1959).

All diluents contained penicillin and streptomycin sulphate $(0.5 \mathrm{mg}$ of each /ml of diluent).

\section{Radio-active chemicals}

These were obtained from the Radiochemical Centre, Amersham, England, and were added separately to the diluents to give the desired concentration and radio-activity. The radio-activity of the substrates was checked in a liquid scintillation counter (Nuclear Chicago).

\section{Preparation of spermatozoal suspensions}

Ejaculates were pooled and the spermatozoa washed by diluting the semen with 3 volumes of diluent and centrifuging for $10 \mathrm{~min}$ at $400 \mathrm{~g}$. After aspirating off all the supernatant, the spermatozoa were washed again and diluted to the appropriate volume with the diluent used for washing.

Incubation of seminal plasma and spermatozoa

Cell-free seminal plasma $(1 \mathrm{mI})$, as in Exp. 1, or suspensions of washed spermatozoa $(0.5 \mathrm{ml})$ plus $0.5 \mathrm{ml}$ of substrate, as in subsequent experiments, 
were incubated at $37^{\circ} \mathrm{C}$ in $6 \mathrm{ml}$ Warburg flasks containing $\mathrm{CO}_{2}$-free $20 \%$ $(\mathrm{w} / \mathrm{v}) \mathrm{KOH}$ in the centre well. The manometers were filled with air and shaken at 114 strokes/min over a period of $3 \mathrm{hr}$ to measure oxygen uptake. The oxidation of substrate was determined from the assay of ${ }^{14} \mathrm{CO}_{2}$ trapped in the $\mathrm{KOH}$ in the centre well. The results are expressed as $\mu$ atoms of $\mathrm{C}$ oxidized and can be converted to $\mu$ moles of substrate oxidized by dividing by the number of $\mathrm{G}$ atoms in the molecule. Sperm respiration in the presence of $\mathrm{CO}_{2}$ and bicarbonate (Exp. 6) was studied by using single-side-arm Warburg flasks and the method of Pardee (1949) as modified by Krebs (1951). Appropriate amounts of Krebs' ' $\mathrm{CO}_{2}$-buffer' (4 $\mathrm{m}$-2,2'-iminodiethanol with $0.1 \%$ thiourea) were added to the side-arm to give a $2 \% \mathrm{CO}_{2}$ atmosphere above the fluid after equilibration. The flasks were then gassed for 2 to $3 \mathrm{~min}$ with $5 \% \mathrm{CO}_{2}-95 \%$ $\mathrm{O}_{2}$ and allowed to equilibrate for $10 \mathrm{~min}$ with stop-cocks open. The stop-cocks were then closed and a further $15 \mathrm{~min}$ allowed for the atmosphere above the fluid in the flask to reach the proper $\mathrm{CO}_{2}$ concentration. Flasks having no $\mathrm{CO}_{2}$ in the atmosphere had $\mathrm{KOH}$ in the sidearm and were closed the entire $25 \mathrm{~min}$ period so that all $\mathrm{CO}_{2}$ would be removed. For experiments requiring anaerobic conditions, single-side-arm Warburg flasks containing $20 \%(\mathrm{w} / \mathrm{v}) \mathrm{KOH}$ in the centre well and yellow phosphorus in the side-arm were gassed for $10 \mathrm{~min}$ with nitrogen.

A portion $(1 \mathrm{ml})$ of spermatozoal suspensions before incubation and of the flask contents after incubation were deproteinized with $0.3 \mathrm{~N} \mathrm{Ba}(\mathrm{OH})_{2}(0.5$ $\mathrm{ml})$ and $5 \%(\mathrm{w} / \mathrm{v}) \mathrm{ZnSO}_{4} .7 \mathrm{H}_{2} \mathrm{O}(0.5 \mathrm{ml})$ and glucose, fructose and lactate estimated in the filtrates. Counts of spermatozoa were made in duplicate and all values expressed on a $10^{8}$ cells basis over the experimental period. The final spermatozoal concentrations were 1.5 to $3.0 \times 10^{8} / \mathrm{ml}$.

\section{Analytical methods}

Lactate was determined by the enzymic method of Barker \& Britton (1957) and glucose by glucose oxidase (Huggett \& Nixon, 1956). Fructose was estimated by the method of Mann (1948) with an incubation period of $20 \mathrm{~min}$ for colour development (White, 1959). The amount of substrate utilized was calculated from the amounts in the flask at the start and end of experiments.

\section{Assay of radio-activity}

The ${ }^{14} \mathrm{CO}_{2}$ absorbed in the centre well, and removed from there by washing, was precipitated as $\mathrm{Ba}^{14} \mathrm{CO}_{3}$ in the presence of $5 \%$ ammonium chloride. The $\mathrm{Ba}^{14} \mathrm{CO}_{3}$ was collected by filtration on Whatman No. 542 paper as described by Annison \& White (1961) and assayed for radio-activity with an end-window Geiger-Müller tube. The counts were corrected for self-absorption by the method of Hendler (1959).

\section{Statistical analyses}

The statistical significance of the results has been assessed by analyses of variance and the residual mean square is given in italics at the base of the variance ratio columns in the tables.

In some experiments the significance of difference between treatments has 
been assessed by a $t$-test using the interaction mean square from the analysis of variance to determine standard error (S.E.) of differences between means as presented in these tables.

Where comparisons to be made between the oxidation of labelled substrates could not be decided in advance of performing the experiment (Table 4), the multiple-range test (Duncan, 1955) was used to compare treatment means.

\section{RESULTS}

\section{Experiment 1 . Oxygen uptake of seminal plasma}

In view of early reports that the oxygen consumption of human seminal plasma is characteristically high (Ross, Miller \& Kurzrok, 1941; MacLeod, 1941), comparisons were made with bull seminal plasma. Text-fig. 1 shows that

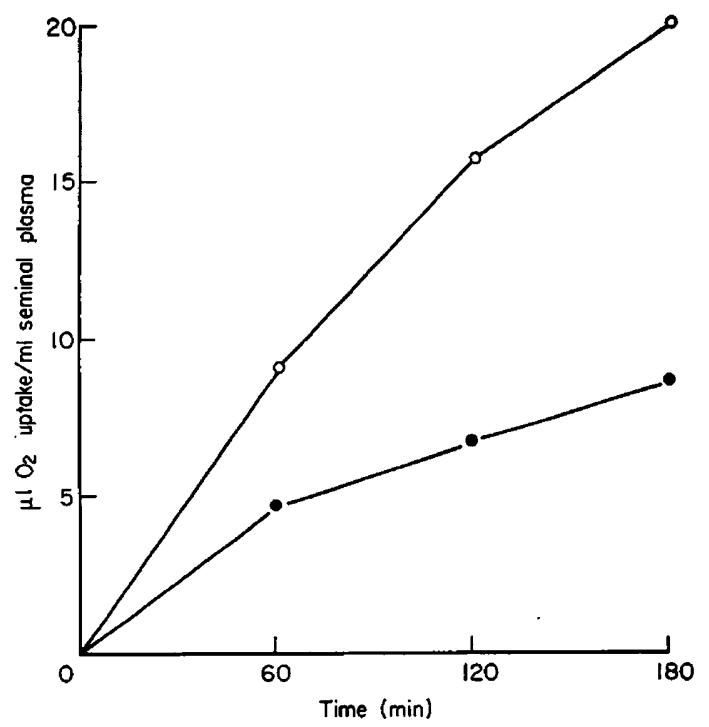

TExT-Fig. 1. The oxygen uptake of human $(O)$ and bull $(0)$ seminal plasma incubated at $37^{\circ} \mathrm{C}$ for $3 \mathrm{hr}$. Values represent the means of six ejaculates for each species.

the oxygen uptake of human seminal plasma $(9 \cdot 2 \mu \mathrm{l} / \mathrm{ml} / \mathrm{hr})$ is more than twice that of the bull $(4 \cdot 6 \mu \mathrm{l} / \mathrm{ml} / \mathrm{hr})$.

\section{Experiment 2. Effect of $p H$ and phosphate on the metabolism of fructose}

The $\mathrm{pH}$ of human semen obtained from four donors within 3 to $4 \mathrm{~min}$ of ejaculation was measured in a pH meter immediately and at regular intervals for $8 \mathrm{hr}$ when the semen was left standing in open tubes ( $15 \mathrm{~mm}$ internal diameter). The initial $\mathrm{pH}$ was $7 \cdot 5 \pm 0.25$ and remained constant over the 8-hr period at room temperature. Since, however, human spermatozoa show maximum motility at about pH 8.5 (Blackshaw \& Emmens, 1951), the rate of metabolism at this $\mathrm{pH}$ was compared with that at $\mathrm{pH} 7 \cdot 0$. The effect of $20 \mathrm{~mm}$-phosphate was also investigated in this experiment.

Table 1 shows that the higher $\mathrm{pH}$ significantly reduced the oxidative metabolism of human spermatozoa but increased fructolysis. At $\mathrm{pH} 7 \cdot 0$, phosphate 
decreased oxidative metabolism whereas at $\mathrm{pH} 8.5$ an increase was observed in the presence of phosphate. Phosphate ions, however, increased fructolysis irrespective of the $\mathrm{pH}$ of the medium.

\section{Experiment 3. Effect of phosphate on the metabolism of acetate and lactate}

To ascertain whether phosphate depressed the oxidation of fructose by inhibiting the oxidation of its breakdown products, the metabolism of lactate and acetate was studied in the presence and absence of $20 \mathrm{~mm}$-phosphate (Table 2).

\section{TABLE 1}

EFFECTS OF PH AND PHOSPHATE IONS (20 mM) ON THE METABOLISM OF D-[U- $\left.{ }^{14} \mathrm{C}\right]$ FRUCTOSE BY WASHED HUMAN SPERMATOZOA

\begin{tabular}{|c|c|c|c|c|c|}
\hline $\begin{array}{c}\text { Phosphate } \\
\text { (mM) }\end{array}$ & $p H$ & $\begin{array}{c}\text { Oxygen } \\
\text { uptake } \\
(\mu l)\end{array}$ & 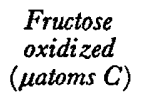 & $\begin{array}{c}\text { Fructose } \\
\text { utilized } \\
\text { ( } \mu \text { moles) }\end{array}$ & $\begin{array}{c}\text { Lactate } \\
\text { produced } \\
\text { ( } \text { (umoles) }\end{array}$ \\
\hline 0 & $\begin{array}{l}7 \cdot 0 \\
8 \cdot 5\end{array}$ & $\begin{array}{r}16 \cdot 3 \\
6 \cdot 9\end{array}$ & $\begin{array}{l}0.420 \\
0.090\end{array}$ & $\begin{array}{l}0.75 \\
0.78\end{array}$ & $\begin{array}{l}1 \cdot 34 \\
1 \cdot 45\end{array}$ \\
\hline 20 & $\begin{array}{l}7 \cdot 0 \\
8.5\end{array}$ & $\begin{array}{r}11 \cdot 9 \\
8 \cdot 9\end{array}$ & $\begin{array}{l}0.318 \\
0 \cdot 120\end{array}$ & $\begin{array}{l}0.93 \\
1.16\end{array}$ & $\begin{array}{l}1 \cdot 84 \\
2 \cdot 26\end{array}$ \\
\hline
\end{tabular}

SUMMARY OF THE ANALYSES OF VARIANCE

\begin{tabular}{l|c|c|c|c|c}
\hline \multirow{2}{*}{ Source of variation } & \multirow{2}{*}{ d.f. } & \multicolumn{4}{|c}{ Variance ratios } \\
\cline { 2 - 6 } & & $\begin{array}{l}\text { Oxygen } \\
\text { uptake }\end{array}$ & $\begin{array}{c}\text { Fructose } \\
\text { oxidized }\end{array}$ & $\begin{array}{c}\text { Fructose } \\
\text { utilized }\end{array}$ & $\begin{array}{c}\text { Lactate } \\
\text { produced }\end{array}$ \\
\hline Effect of phosphate & 1 & $1 \cdot 15$ & $1 \cdot 44$ & $14 \cdot 60^{* *}$ & $43 \cdot 04^{* *}$ \\
Effect of pH & 1 & $32 \cdot 76^{* *}$ & $77 \cdot 18 * *$ & $3 \cdot 19$ & $7 \cdot 15^{*}$ \\
Interaction & 1 & $8 \cdot 45^{*}$ & $4 \cdot 82$ \\
Between replicates & 2 & $23 \cdot 64^{* *}$ & $8 \cdot 69^{*}$ & $1 \cdot 78$ & $2 \cdot 28$ \\
Residual & 6 & $3 \cdot 56$ & 0.0027 & 0.0163 & $1 \cdot 18$ \\
& & & & 0.0302 \\
\hline
\end{tabular}

Values represent the means of three replicates and are calculated $/ 10^{8}$ spermatozoa/ $3 \mathrm{hr} .4 .5 \mu$ moles, $200 \mu \mathrm{mc}$ of labelled fructose were added to each flask.

Lactate was more effective than acetate in increasing the oxygen uptake of human spermatozoa and was oxidized at a much faster rate. Phosphate depressed the oxidation of both substrates as judged by the sensitive oxygen uptake and ${ }^{14} \mathrm{C}$ data although it was not possible to detect any depression of lactate utilization by chemical estimation.

Experiment 4. Effect of potassium on the aerobic and anaerobic metabolism of fructose

Table 3 shows the effect of potassium ( $15 \mathrm{~mm}$ ) on the aerobic and anaerobic metabolism of fructose by human spermatozoa.

Potassium ions stimulated both oxidative metabolism and fructolysis, the greatest effects on fructose utilization and lactate production being seen under aerobic conditions. 
TABLE 2

EFFECT OF PHOSPHATE IONS (20 MM) ON THE METABOLISM OF $\left[1-{ }^{14} \mathrm{c}\right]$ AGETATE AND $\left[1-{ }^{14} \mathrm{C}\right]$ LAGTATE BY WASHED HUMAN SPERMATOZOA

\begin{tabular}{|c|c|c|c|c|}
\hline $\begin{array}{l}\text { Phosphate } \\
\text { (mM) }\end{array}$ & Substrate & $\begin{array}{c}\text { Oxygen } \\
\text { uptake } \\
(\mu l)\end{array}$ & 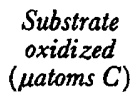 & $\begin{array}{l}\text { Lactate } \\
\text { utilized } \\
\text { (umoles) }\end{array}$ \\
\hline 0 & $\begin{array}{l}{\left[1-{ }^{14} \mathrm{C}\right] \text { Acetate }} \\
{\left[1-{ }^{14} \mathrm{C}\right] \text { Lactate }}\end{array}$ & $\begin{array}{l}20 \cdot 7 \\
26 \cdot 7\end{array}$ & $\begin{array}{l}0.182 \\
0.581\end{array}$ & $\overline{0.16}$ \\
\hline 20 & $\begin{array}{l}{[1-14 \mathrm{C}] \text { Acetate }} \\
{\left[1-^{14} \mathrm{C}\right] \text { Lactate }}\end{array}$ & $\begin{array}{l}17 \cdot 1 \\
21 \cdot 6\end{array}$ & $\begin{array}{l}0.138 \\
0.488\end{array}$ & $\overline{0.17}$ \\
\hline
\end{tabular}

SUMMARY OF THE ANALYSES OF VARIANCE

\begin{tabular}{l|c|c|c}
\hline \multirow{2}{*}{ Source of variation } & d.f. & \multicolumn{2}{|c}{ Variance ratios } \\
\cline { 3 - 4 } & & $\begin{array}{c}\text { Oxygen } \\
\text { uptake }\end{array}$ & $\begin{array}{c}\text { Substrate } \\
\text { oxidized }\end{array}$ \\
\hline Effect of phosphate & 1 & $7.48^{*}$ & $10.23^{*}$ \\
Effect of substrate & 1 & $10.92^{* *}$ & $306 \cdot 10^{* *}$ \\
Interaction & 1 & 0.20 & $1 \cdot 31$ \\
Between replicates & 3 & $6.04^{*}$ & $4.80^{*}$ \\
Residual & 9 & 10.04 & 0.002 \\
\hline \multicolumn{2}{c}{$* P<0.05 ; * * P<0.01}$.
\end{tabular}

Values represent the means of four replicates and are calculated $/ 10^{8}$ spermatozoa $/ 3 \mathrm{hr}$. The amounts of substrate added to each flask were: acetate, $27 \mu$ moles, $200 \mu \mathrm{mc}$; lactate, $18 \mu$ moles, $200 \mu \mathrm{mc}$.

\section{TABLE 3}

EFFECT OF POTASSIUM IONS ( $15 \mathrm{mM}$ ) ON THE AEROBIC AND ANAEROBIC METABOLISM OF D- $\left[\mathrm{U}^{-14} \mathrm{C}\right]$ FRUGTOSE BY WASHED HUMAN SPERMATOZOA

\begin{tabular}{c|l|c|c|c|c}
\hline $\begin{array}{c}\text { Potassium } \\
(\mathrm{mM})\end{array}$ & $\begin{array}{c}\text { Gas } \\
\text { phase }\end{array}$ & $\begin{array}{c}\text { Oxygen } \\
\text { uptake } \\
(\mu \mu)\end{array}$ & $\begin{array}{c}\text { Fructose } \\
\text { oxidized } \\
(\mu \text { atoms } C)\end{array}$ & $\begin{array}{c}\text { Fructose } \\
\text { utilized } \\
(\mu \text { moles })\end{array}$ & $\begin{array}{c}\text { Lactate } \\
\text { produced } \\
(\mu m o l e s)\end{array}$ \\
\hline \multirow{2}{*}{0} & Aerobic & 15.8 & 0.299 & 0.98 & 1.64 \\
& Anaerobic & - & - & 0.90 & 1.79 \\
& Aerobic & 19.6 & 0.423 & 1.10 & 2.23 \\
& Anaerobic & - & - & 1.06 & 1.96 \\
\hline
\end{tabular}

SUMMARY OF THE ANALYSES OF VARIANCE

\begin{tabular}{|c|c|c|c|c|c|}
\hline \multirow{2}{*}{ Source of variation } & \multirow{2}{*}{ d.f. } & \multicolumn{4}{|c|}{ Variance ratios } \\
\hline & & $\begin{array}{l}\text { Oxygen } \\
\text { uptake }\end{array}$ & $\begin{array}{l}\text { Fructose } \\
\text { oxidized }\end{array}$ & $\begin{array}{l}\text { Fructose } \\
\text { utilized }\end{array}$ & $\begin{array}{c}\text { Lactate } \\
\text { produced }\end{array}$ \\
\hline $\begin{array}{l}\text { Effect of potassium } \\
\text { Effect of gas phase } \\
\text { Interaction } \\
\text { Between replicates } \\
\text { Residual }\end{array}$ & $\begin{array}{l}1 \\
1 \\
1 \\
3 \\
3\end{array}$ & $\begin{array}{c}8 \cdot 52 \\
- \\
- \\
3 \cdot 57 \\
3 \cdot 39\end{array}$ & $\begin{array}{l}34 \cdot 25 * * \\
- \\
\overline{1} \cdot 49 \\
0.0009\end{array}$ & $\begin{array}{l}19 \cdot 95^{* *} \\
3 \cdot 75 \\
0.35 \\
6 \cdot 20^{*} \\
0.004 \dagger\end{array}$ & $\begin{array}{l}28 \cdot 89 * * \\
0 \cdot 65 \\
8 \cdot 68 * \\
6 \cdot 62^{*} \\
0 \cdot 0196 \dagger\end{array}$ \\
\hline
\end{tabular}

Values represent the means of four replicates and are calculated/10 8 spermatozoa/ $3 \mathrm{hr} .9 \mu \mathrm{moles}, 200 \mu \mathrm{mc}$ of labelled fructose were added to each flask. 
Experiment 5. Comparison of rate of oxidation of sugars, polyols and acetate

The rate of metabolism of labelled glucose, fructose, glycerol, sorbitol and acetate by human spermatozoa is shown in Table 4 .

Glucose and fructose were oxidized at about the same rate and gave rise to about equal amounts of lactate. Glycerol, sorbitol and acetate were oxidized less readily but only the two polyols produced a statistically significant increase

TABLE 4

METABOLISM OF GLUCOSE, FRUCTOSE, GLYGEROL, SORBITOL AND ACETATE BY WASHED HUMAN SPERMATOZOA

\begin{tabular}{|c|c|c|c|c|c|}
\hline \multirow[t]{2}{*}{ Substrate } & \multicolumn{3}{|c|}{$\begin{array}{l}\text { Progressive oxygen uptake } \\
(\mu \bar{l})\end{array}$} & \multirow{2}{*}{ 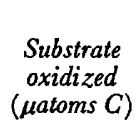 } & \multirow{2}{*}{$\begin{array}{c}\text { Lactate } \\
\text { produced } \\
(\mu \text { moles })\end{array}$} \\
\hline & $1 \mathrm{hr}$ & $2 \mathrm{hr}$ & $3 \mathrm{hr}$ & & \\
\hline $\begin{array}{l}\text { Control } \\
\mathrm{D}-\left[\mathrm{U}-{ }^{14} \mathrm{C}\right] \text { glucose } \\
\mathrm{D}-\left[\mathrm{U}-{ }^{14} \mathrm{C}\right] \text { fructose } \\
{\left[\mathrm{I}^{14} \mathrm{C}\right] \text { glycerol }} \\
{\left[\mathrm{U}-1^{14} \mathrm{C}\right] \text { sorbitol }} \\
{\left[\mathrm{I}-{ }^{14} \mathrm{C}\right] \text { acetate }}\end{array}$ & $\begin{array}{l}4 \cdot 9 \\
5 \cdot 3 \\
4 \cdot 8 \\
5 \cdot 7 \\
5 \cdot 4 \\
4 \cdot 8\end{array}$ & $\begin{array}{r}9 \cdot 3 \\
10 \cdot 4 \\
9 \cdot 0 \\
11 \cdot 0 \\
10 \cdot 7 \\
9 \cdot 7\end{array}$ & $\begin{array}{l}11 \cdot 9 \\
13 \cdot 0 \\
12 \cdot 0 \\
14 \cdot 2 * \\
14 \cdot 1^{*} \\
12 \cdot 6 \\
0 \cdot 82\end{array}$ & $\begin{array}{l}- \\
0.215 \\
0.231 \\
0 \cdot 107 \\
0.131 \\
0.113\end{array}$ & $\begin{array}{l}- \\
1 \cdot 89 \\
2 \cdot 02 \\
\text { Trace } \\
\text { Trace } \\
-\end{array}$ \\
\hline
\end{tabular}

* Significantly different from control, $P<0 \cdot 05$.

Values represent the means of four replicates and are calculated $/ 10^{8}$ spermatozoa. The amount of substrate added to each flask was: $\mathrm{D}-\left[\mathrm{U}-{ }^{14} \mathrm{C}\right]$ glucose, $9 \mu \mathrm{moles}, 500 \mu \mathrm{mC}$; $\mathrm{D}-\left[\mathrm{U}-{ }^{14} \mathrm{C}\right]$ fructose, $9 \mu \mathrm{moles}, 500 \mu \mathrm{mc}$; $\left[1 .{ }^{14} \mathrm{C}\right]$ glycerol, $18 \mu \mathrm{moles}, 500 \mu \mathrm{mc}$; [U-14 $\mathrm{C}$ ] sorbitol, $9 \mu$ moles, $500 \mu \mathrm{mc} ;\left[1{ }^{14} \mathrm{C}\right]$ acetate, $27 \mu$ moles, $500 \mu \mathrm{mc}$.

For the substrate oxidized values, the multiple range test gave the following ranking: glucose $=$ fructose $>$ glycerol $=$ sorbitol $=$ acetate $(P<0.05)$.

TABLE 5

EFFECT OF BICARBONATE ON THE METABOLISM OF GLUCOSE BY WASHED HUMAN SPERMATOZOA

\begin{tabular}{|c|c|c|c|c|c|}
\hline \multirow{2}{*}{$\begin{array}{l}\text { Bicarbonate } \\
(\mathrm{mM})\end{array}$} & \multicolumn{3}{|c|}{$\begin{array}{l}\text { Progressive oxygen uptake } \\
\qquad(\mu l)\end{array}$} & \multirow{2}{*}{$\begin{array}{c}\text { Glucose } \\
\text { utilized } \\
\text { ( } \mu \text { moles) }\end{array}$} & \multirow{2}{*}{$\begin{array}{c}\text { Lactate } \\
\text { produced } \\
(\mu \text { moles })\end{array}$} \\
\hline & $1 \mathrm{hr}$ & $2 \mathrm{hr}$ & $3 \mathrm{hr}$ & & \\
\hline 0 & $4 \cdot 2$ & $8 \cdot 3$ & 10.7 & $1 \cdot 13$ & $2 \cdot 11$ \\
\hline $6 \cdot 00$ & $5 \cdot 0$ & $8 \cdot 7$ & $12 \cdot 0^{* *}$ & 1.20 & $2 \cdot 30$ \\
\hline & & & S.E. $=0.13$ & S.E. $=0.037$ & S.E. $=0.91$ \\
\hline
\end{tabular}

** Highly significantly different from $0 \mathrm{~mm}$ bicarbonate. $P<0.01$.

Values represent the means of three replicates and are calculated $/ 10^{8}$ spermatozoa. $9 \mu$ moles of glucose were added to each flask.

in oxygen uptake above that of the controls. Trace amounts of lactate could be detected when glycerol or sorbitol were used as substrate but none was present. with acetate.

Experiment 6. Effect of bicarbonate on the metabolism of glucose

Sodium bicarbonate $(6.00 \mathrm{~mm})$ slightly increased the oxygen uptake of human spermatozoa but had no significant effect on glycolytic activity (Table 5). 


\section{DISCUSSION}

Our estimate of the $\mathrm{pH}$ of freshly ejaculated human semen using a glass electrode agrees with previous published data (Schuermann \& Doepfmer, 1960; Mann, 1964; Raboch \& Skachova, 1965). We did not, however, find any evidence of a rise in $\mathrm{pH}$ on standing, as apparently sometimes occurs with ejaculates of low sperm concentration (see White \& MacLeod, 1963). pH papers have, in our experience, proved unreliable and may give values up to $1.0 \mathrm{pH}$ units above that of the glass electrode. The finding that fructolysis proceeds at a faster rate at $\mathrm{pH} \mathrm{8.5} \mathrm{than} \mathrm{at} \mathrm{pH} 7.0$ may explain the observation of Blackshaw \& Emmens (1951) that human spermatozoa show maximum motility under alkaline conditions.

The high oxygen uptake of human seminal plasma compared to that of the bull may be accounted for by the presence of a spermine-diamine oxidase system in human seminal plasma (Zeller, 1941). At all events, spermine occurs in high concentrations in human semen (Mann, 1964) but bull semen contains only a trace. The seminal plasma in human semen consumes about twice as much oxygen as the spermatozoa ( 9 versus $5 \mu \mathrm{l} / \mathrm{hr} / \mathrm{ml}$ of semen). By contrast, the oxygen consumption of the seminal plasma in bull semen is less than a tenth that of spermatozoa (5 versus $70 \mu \mathrm{l} / \mathrm{hr} / \mathrm{ml}$ of semen-see Murdoch \& White, 1966a). The oxygen uptake of the individual spermatozoon is, however, comparable for the two species, i.e. human, about $5 \mu \mathrm{l} / 10^{8}$ spermatozoa/hr; bull, about $7 \mu \mathrm{l} / 10^{8} \mathrm{cells} / \mathrm{hr}$. Our results leave little doubt that human spermatozoa, like those of the bull and other mammals examined, have an actively functioning oxidative system since the oxygen uptake of the plasma-free spermatozoa has been accurately measured along with the radio-active ${ }^{14} \mathrm{CO}_{2}$ produced from labelled substrates.

Human spermatozoa resemble ram and bull in their response to phosphate and potassium (cf. Lardy \& Phillips, 1943; White, 1953; Wallace \& Wales, 1964; Lodge, Salisbury, Schmidt \& Graves, 1963; Wales \& Wallace, 1964) and the depressing effect of phosphate on oxygen uptake at $\mathrm{pH} 7.0$ would, as Rothschild (1960) suggests, make respiration more difficult to measure. Since the oxidation of acetate is depressed to about the same extent as lactate, the rate-limiting action of phosphate may be concerned with the entry of acetyl CoA into the Krebs cycle and not merely with inhibition of lactic dehydrogenase (Rothschild, 1960). The stimulatory effect of phosphate on the breakdown of fructose to lactic acid is not unexpected in view of the large number of phosphate intermediates in the Embden-Meyerhof series of reactions. Since potassium stimulates anaerobic as well as aerobic fructolysis in human spermatozoa it must have a stimulatory effect on the Embden-Meyerhof pathway as well probably as Krebs-cycle reactions as also shown in the ram and bull (Dott \& White, 1964; Wales \& O'Shea, 1966; Murdoch \& White, 1966b).

Human spermatozoa clearly oxidize glucose more readily than acetate (Terner, 1960; Minassian \& Terner, 1966) and fall into the pattern of other non-ruminant spermatozoa (e.g. dog and rabbit) in this respect (Scott, White \& Annison, 1962; Murdoch \& White, 1966a). Human spermatozoa, like those of other mammalian species (Mann \& White, 1956, 1957; White, 1957; O'Shea \& 
Wales, 1965), also have the ability to oxidize sorbitol which is present in semen and is metabolized via the glycolytic cycle after conversion to fructose (King \& Mann, 1959; O'Shea \& Wales, 1965). Only trace amounts of lactate were produced by human spermatozoa, however, when either sorbitol or glycerol was used as substrate. This suggests that the conversion of glycerol to phosphoglycerol and of sorbitol to fructose in human spermatozoa is slow and only just adequate to meet the demands of the Krebs cycle after the conversion products have entered the glycolytic pathway. Since fructose and glucose give rise to a considerable amount of lactate under aerobic conditions glycolysis must proceed at a greater rate than the Krebs cycle reactions in human spermatozoa. The results, however, dispel any doubt that human spermatozoa can oxidize lactate and glycerol (see White \& MacLeod, 1963). Ram and bull spermatozoa are also able to oxidize glycerol (White, Blackshaw \& Emmens, 1954; O’Dell, Flipse \& Almquist, 1956; Mann \& White, 1956, 1957; White, 1957) but it seems unlikely that the protective action of glycerol at low temperatures is dependent upon its metabolism by spermatozoa.

The stimulating effect of bicarbonate on the respiration of human spermatozoa confirms the work of Hamner \& Williams (1964) although the magnitude of our stimulation was not as great. Bull, rooster and rabbit spermatozoa show a similar response to bicarbonate (Hamner \& Williams, 1964; Murdoch \& White, unpublished data) and the former authors suggest that the stimulation is due to an increase in the concentration of Krebs-cycle intermediates.

Since the addition of exogenous substrates such as glucose, fructose and acetate failed to increase the oxygen uptake of human spermatozoa above the control, these substances must cause a decrease in the oxidation of endogenous substrate in the spermatozoa, as has been observed in the ram and bull (Scott, White \& Annison, 1962). The nature of the endogenous substrate in human spermatozoa is not known with any certainty but is most likely phospholipid.

It is concluded that, in general, the metabolic behaviour of human spermatozoa in vitro resembles that of other mammalian species although there may be some quantitative differences.

\section{ACKNOWLEDGMENTS}

We are indebted to Professor G. W. Emmens for his interest and advice. The work has been aided by grants from the Ford Foundation and the Australian Dairy Produce Board. One of us (R.N.M.) was supported by an F. W. Loxton Post-Graduate Studentship.

\section{REFERENCES}

Annison, E. F. \& Whrte, R. R. (1961) Glucose utilization in sheep. Biochem. 7. 80, 162.

Barker, J. N. \& Brtton, H. G. (1957) The enzymatic estimation of $L(+)$ lactic acid. F. Physiol., Lond. 138, 3P.

Blackshaw, A. W. \& Emmens, C. W. (1951) The interaction of $\mathrm{pH}$, osmotic pressure and electrolyte concentration on the motility of ram, bull and human spermatozoa. F. Physiol., Lond. 114, 16.

DotT, H. M. \& Whrte, I. G. (1964) Effect of potassium on ram spermatozoa studied by flow dialysis technique. 7. Reprod. Fert. 7, 127.

Duncan, D. B. (1955) Multiple range and multiple F tests. Biometrics, 11, I. 
Hamner, C. E. \& Williams, W. L. (1964) Identification of sperm stimulating factor of rabbit oviduct fluid. Proc. Soc. exp. Biol. Med. 117, 240.

Hendler, R. W. (1959) Self-absorption correction for carbon-14. Science, N. $Y .130,772$.

Huggetr, A. St.G. \& Nixon, D. A. (1956) Enzymic determination of blood glucose. Biochem. 7. 66, 12 p.

King, T. E. \& Mand, T. (1959) Sorbitol metabolism in spermatozoa. Proc. R. Soc. B, $151,226$.

Krebs, H. A. (195I) The use of ' $\mathrm{CO}_{2}$ Buffers' in manometric measurements of cell metabolism. Biochem. F. 48, 349.

Lardy, H. A. \& Phillips, P. H. (1943) Effect of pH and certain electrolytes on the metabolism of ejaculated spermatozoa. Am. F. Physiol. 138, 741 .

Lodge, J. R., Salisbury, G. W., Sammidt, R. P. \& Graves, C. N. (1963) Effect of phosphate and of related co-factors on the metabolism of bovine spermatozoa. 7. Dairy Sci. 46, 473.

Macleod, J. (1941) The metabolism of human spermatozoa. Am. $\mathcal{J}$. Physiol. 132, 193.

MAcLeOD, J. (1943) The role of oxygen in the metabolism and motility of human spermatozoa. Am. $\mathcal{J}$. Physiol. 138, 512.

MacLeod, J. (1956) Human semen. Fert. Steril. 7, 368.

MACLEOD, J. \& Freund, M. (1958) Influence of spermatozoal concentration and initial fructose level on fructolysis in human semen. 7. appl. Physiol. 13, 501.

Mann, T. (1948) Fructose content and fructolysis in semen. Practical application in the evaluation of semen quality. 7. agric. Sci., Camb. 38, 323.

Mann, T. (1951) Studies on the metabolism of semen. 7. Cytochrome in human spermatozoa. Biochem. 7. $48,386$.

Mann, T. (1964) The biochemistry of semen and of the male reproductive tract. Methuen, London.

Mann, T. \& Whrre, I. G. (1956) Metabolism of glycerol, sorbitol and related compounds by spermatozoa. Nature, Lond. 178, 142.

ManN, T. \& White, I. G. (1957) Glycerol metabolism by spermatozoa. Biochem. 7. 65, 634.

Minassian, E. S. \& Terner, C. (1966) Biosynthesis of lipids by human and fish spermatozoa. $A m$. $\mathcal{F}$. Physiol. 210, 615.

Murdoch, R. N. \& White, I. G. (1966a) The metabolism of glucose, fructose, acetate, lactate and pyruvate by ram, bull, dog and rabbit spermatozoa. 7. Reprod. Fert. 12, 271.

Murdoch, R. N. \& White, I. G. (1966b) Factors affecting the metabolism of acetate and glucose by ram and bull spermatozoa. Aust. F. biol. Sci. 19, 857.

Nevo, A. C. (1966) Relation between motility and respiration in human spermatozoa. 7 . Reprod. Fert. $11,19$.

O'Dell, W. T., Flipse, R. J. \& Almquist, J. O. (1956) Metabolism of bovine semen. III. Uptake and metabolic utilization of glycerol-1- $\mathrm{C}^{14}$ by bovine spermatozoa. 7 . Dairy Sci. 39, 214.

O'SheA, T. \& Wales, R. G. (1965) Metabolism of sorbitol and fructose by ram spermatozoa. $\mathcal{J}$. Reprod. Fert. 10, 353.

Pardee, A. B. (1949) Measurement of oxygen uptake under controlled pressure of carbon dioxide. 7. biol. Chem. 179, 1085.

Raboch, J. \& Skachova, J. (1965) The pH of human ejaculate. Fert. Steril. 16, 252.

Ross, V., Miller, E. G. \& Kurzrok, R. (1941) Metabolism of human sperm. Endocrinology, $28,885$.

Rothschild, LORD (1960) The heat production of human spermatozoa and seminal plasma; with comparative observations on bull semen. Proc. R. Soc. B, 152, 298.

Schuermann, H. \& Doepfmer, R. (1960) Fertilitätsstörungen beim Manne. Springer, Berlin.

Scotт, T. W., White, I. G. \& Annison, E. F. (1962) Glucose and acetate metabolism by ram, bull, dog and fowl spermatozoa. Biochem. F. 83, 398.

Terner, C. (1960) Oxidation of exogenous substrates by isolated human spermatozoa. Am. J. Physiol. $198,48$.

Umbreit, W. W., Burris, R. H. \& Stauffer, J. F. (1959) Manometric techniques. Burgess Publishing Co., Minneapolis.

Wales, R. G. \& Wallace, J. C. (1964) Effects of diluent composition on the metabolism of bull, rabbit and fowl spermatozoa. 7. Reprod. Fert. 8, 36.

Wales, R. G. \& O'SheA, T. (1966) The oxidative utilization of fructose and acetate by washed ram spermatozoa in the presence or absence of potassium and magnesium. Aust. F. biol. Sci. 19, 167.

Wallace, J. C. \& WALES, R. G. (1964) Effect of ions on the metabolism of ejaculated and epididymal ram spermatozoa. 7. Reprod. Fert. 8, 187.

White, I. G. (1953) Metabolic studies of washed and diluted ram and bull spermatozoa. Aust. F. biol. Sci. 6, 706.

White, I. G. (1957) Metabolism of glycerol and similar compounds by bull spermatozoa. F. Physiol. $189,307$. 
WhITE, I. G. (1959) Studies on the estimation of glycerol, fructose and lactic acid with particular reference to semen. Aust. 7. exp. Biol. med. Sci. 37, 441.

White, I. G., Blackshaw, A. W. \& Emmens, G. W. (1954) Metabolic and motility studies relating to the low temperature storage of ram and bull spermatozoa. Aust. vet. $\mathbf{7} .30,85$.

White, I. G. \& MACLeod, J. (1963) Mechanisms concerned with conception. Ed. C. G. Hartman. Pergamon Press, New York.

Zel.ler, E. A. (1941) Ueber das Vorkommen der Diamin-oxydase im menschlichen sperma. Helv. chim. Acta, 24, 117. 